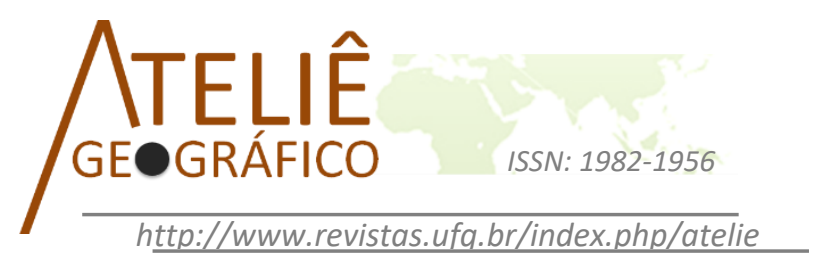

\title{
Global agricultural trade and genetic resources as a point of contention
}

\author{
Comercio agrícola global e recursos genéticos como um \\ ponto de conflito \\ Comercio agrícola global y recursos genéticos como un \\ punto de conflicto
}

\author{
Ricardo Barbosa Jr \\ University of Calgary \\ ricardo.barbosajr@ucalgary.ca
}

Matheus Hoffmann Pfrimer

Universidade Federal de Goiás

matheuspfrimer@hotmail.com

\begin{abstract}
International agricultural trade has greatly altered the way food is grown, negatively affecting peasant livelihood and the natural environment. While the literature on this is extensive, efforts to understand how genetic variety is effected within such a process is limited. Wherefore, in this paper we explore the factors that determine the place of genetic resources in international trade. This is done by creating a conceptual framework to analyse different forms of power, a process necessary due to its contemporary fungible nature, in an attempt to asses how biotechnology can disclose power's other characteristics. We demonstrate how the instrumental use of biotechnology has become an apparatus to control food production globally and a means by which the international market homogenises food production. Through the use of a bio/geopolical gaze we identify that this course occurs within the realm of bioecnomics and geoeconomics.
\end{abstract}

Keywords: international agricultural trade; genetic resources; bio/geopolitics.

\section{Resumo}

O comércio agrícola internacional tem significativamente alterado o modo como os alimentos são cultivados, afetando negativamente os meios de subsistência dos camponeses e o ambiente natural. Embora a literatura sobre isso seja extensa, esforços que buscam entender como a variedade genética é afetada por esse processo são 
limitados. Portanto, neste artigo, exploramos os fatores que determinam o lugar dos recursos genéticos no comércio internacional. Isso é feito ao construir uma estrutura conceitual para analisar diferentes formas de poder, um processo necessário devido à sua natureza fungível contemporânea, na tentativa de analisar como a biotecnologia pode divulgar outras características do poder. Demonstramos como o uso instrumental da biotecnologia tornou-se um aparato para controlar a produção de alimentos globalmente e um meio pelo qual o mercado internacional homogeneíza a produção de alimentos. Através do uso de um olhar bio/geopolítico, identificamos que este curso ocorre no âmbito da bioeconomia e geoeconomia.

Palavras-chave: comércio agrícola internacional; recursos genéticos; bio/geopolítica.

\section{Resumen}

El comercio agrícola internacional ha considerablemente alterado la forma en que se cultivan los alimentos, afectando negativamente los medios de vida de los campesinos y el medio ambiente natural. Si bien la literatura sobre esto es extensa, los intentos de comprender cómo se realiza la variedad genética en este proceso son limitados. Por lo tanto, en este artículo, exploramos los factores que determinan el lugar de los recursos genéticos en el comercio internacional. Esto se hace creando un marco conceptual para analizar diferentes formas de poder, un proceso necesario debido a su naturaleza fungible contemporánea, en un intento de evaluar cómo la biotecnología puede revelar otras características del poder. Demostramos cómo el uso instrumental de la biotecnología se ha convertido en un aparato para controlar la producción de alimentos a nivel mundial y un medio por el cual el mercado internacional homogeneiza la producción de alimentos. A través de una mirada bio/geopolítica identificamos que este curso se procede dentro del ámbito de la bioecnómica y la geoeconomía.

Palabras clave: comercio agrícola internacional; recursos genéticos; bio/geopolítica.

"There was no way, at that point, that I could have imagined that 30 years later the world would have become as commercially integrated - and therefore spiritually and culturally fragmented - as it has become. That human beings could start to get as brutalised as they have been - those who are victims of this very exploitative system, as well as those who perpetuate it because you have to be brutalised in order to try and accumulate other people's shared resources." - Vandana Shiva, 2012.

\section{Introduction}

Capitalist agriculture is fundamentally different from the farming done by peasants (VAN DER PLOEG, 2016); it is profit driven and operates within the logic of international trade (CLAPP; FUCHS, 2009). Technology is the primordial factor that has allowed the practice of farming, which originally referred to a means of maintaining the biological metabolism and thus assuring human life, to be altered so drastically. The Green Revolution was at first envisioned as a solution for human challenges (e.g., the need for long hours of labor and hunger) and yet it proved inept, rather ensuing in high social and environmental costs (PATEL, 2013). In the long run, the Green Revolution has subjected most other forms of farming to a market logic, and while production did initially increase, 
neither the resulting output nor its benefits where distributed (CHAPPELL et al., 2013; MCMICHAEL, 2006; PATNAIK, 2012).

Within the neoliberal free trade regime, technology-based capitalist agriculture acquired global proportions and began effecting localities all over the world (MCMICHAEL, 2014). This has fashioned a new approach to growing food that is structurally different, based on a less diverse value system. Rather than an agriculture that incorporates social, environmental, and economic concerns, the current form of global capitalist agriculture now maximises the last at the cost of the prior. The concurrent process of urbanisation has resulted in the rural-urban divide and the physical and symbolic distancing of food producers and consumers (ALKON, 2013; COCA; BARBOSA JR, 2016), which the internationalisation of agrifood markets widens even further (ALONSO-FRADEJAS et al., 2015). In the end, this has materialised in a distinction between countries that export and import food (BARBOSA JR; PFRIMER, 2016), giving place to an international division of labor, a course that Friedmann (1991) argues is taking place since capitalism became hegemonic.

A particular kind of technology has become indispensable in capitalist agriculture and its process, biotechnology (OTERO, 2012). The technology that allows one to alter life can even be understood as a necessity of the international market, for it has adapted so-called 'exotic crops' to a diverse range of regions across the world where such crops did not previously grow (GRADDY, 2013, 2014). Consequently, there are market interests that now dictate not only how food is grown but also what kinds of food are grown and where. This threatens local agrobiodiversity (ZIMMERER, 2010) and directly affects the variety of food in consumer diets (STÉDILE, 2013). In this paper, we explore a specific aspect of the social and environmental consequences that result from market-determined agriculture. We draw attention to the incongruities that stems from global market parameters dictating the use of genetic resources.

By focussing on the relationship between biotechnology and agriculture in the context of neoliberal global trade we demonstrate how genetic resources, and the control over them, has become even more strategic within the internationalisation of the agricultural market. We assess the consequences that this has on local communities and the environment by appraising the loss of agrobiodiversity. The research is directed by the question: in which ways and to what extent is biotechnology altering power relations amongst different actors in global agricultural? Although non-state actors are relevant and cannot be overlooked, our focus in this paper is on the dynamics and relations of state actors that articulate within the contemporary global agricultural market. Therefore, the analysis is limited to the global and national scales.

The central argument of this paper is that the introduction of biotechnology as an instrument for economic competition perpetuates the instrumentalisation of knowledge and techniques as tools to control life and space (KLOPPENBURG, 2014). This in turn leads to the recurrent homogenisation of agrifood items and drastic reduction of agrobiodiversity. The phenomenon is spearheaded by global corporations in the context 
of international neoliberal free trade regime and the nature of its dynamics of rigged competition (BARBOSA JR; COCA, 2015a).

Inquiry into agriculture reminds us of the significance of land and, hence, the highest relevance is placed on the concept of territory, 1 which in turn refers to the very idea of geopolitics. Disputes over the control of land and territory is a central part of the concern with agriculture. In these terms, agriculture is brought into the realm of geopolitics, understood as the discipline that considers power relations and its spatial forms, processes, and functions. Technological breakthroughs and the diffusion of scientific techniques have likewise allowed the expansion of power to reach the domain of life itself. Biotechnology characterises the conversion of territorial power into biopower in the realm of agricultural trade. Considering this revelation, we theorise biotechnology as an element perceived through a geopolitical and a biopolitical gaze. We go on to describe how geopolitical and biopolitical approaches do not restrict themselves to the political arena, as the nature of power is now fungible. 2 In short, this means that the economic dimension permeates the various domains of territory and life.

In addition to this introduction and the final considerations, this paper divides into four parts. We first carry out an analytical movement that situates and articulates the aforementioned concepts of land, agrobiodiversity, and biotechnology. Thereafter, we describe how biotechnology plays a role in the creation of a bioeconomy, where life is turned into an asset. We then explore the logistical aspect of a geoeconomy where we analyse the materiality of the global agricultural market and discuss the implications for agrobiodiversity. In the concluding section we discuss the results.

\section{Capitalist agriculture and its strategic assets: land, agrobiodiversity, and biotechnology}

Although agriculture has not been traditionally considered a prominent theme in international politics, its relevance to power was well recognised by classical geopoliticians. While analysing the confrontation among sedentary and nomads tribes, Friedrich Ratzel (1987) asserted that settlements occur in a determined territory due to agricultural purposes. This in turn will prompt nomad tribes to create institutions in order to protect their territory. The resulting distinction among sedentary and nomads will latter give rise to different conceptualisations of territory. Foremost, as a space to be controlled

\footnotetext{
${ }^{1}$ The concept of territory is used in reference to a portion of space appropriated by either states or non-state actors. Territory can no longer be conceived as a space controlled and appropriated exclusively by a single political actor, as nowadays territory is characterised by a greater fluidity (GOTTMANN, 1973). For further discussion on territory, see the work of Delaney (2005).

${ }^{2}$ For more on the fungible nature of power see Pfrimer, Coca, and Barbosa Jr (2016) and Pfrimer and Barbosa Jr (2017).
} 
from a Platonian standpoint and, secondarily, as a space of circulation and integration following an Aristotelian perspective.

In a classical sense, geopolitics is defined as the discipline that appraises political power through territorial arrangements among political units. Through this perspective geopolitics deals with political power and its repercussion over state-centric territorial extension and organisation. However, the technological and scientific revolution has rendered the nature of political power multidimensional. Power is now exerted by varied actors, from diverse positions. As presented by the well-known Brazilian geopolitician Bertha Becker, political power and territory acquires different meanings nowadays. In an attempt of reframing the concept, she envisions geopolitics from a foucauldian perspective as the discipline that handles the various dimensions of power exerted through territorial organisation.

Becker (2007) sheds light on how political power can now be understood through its multiple forms. While conceiving the nature of political power as fungible, the author asserts that geopolitical power deals not only with the political sector but equally with other dimensions, since geopolitics is the continuation of war by different means, and as such, geopolitics can even be converted into geoeconomy. In this sense, competition among diverse actors does not restrict itself to political contention, but expands to other domains such as the logistical realm. In other words, the organisation of space through the disposition of diverse infrastructure allows certain extension of space to be compressed as a result of the manipulation of time (HARVEY, 1992). Other authors have deepened this conception in order to address power as a coin whose different sides are composed of geopolitics and the biopolitics (BRAUN, 2007; INGRAM, 2009).

According to Braun (2007), in the molecular age, the instrumentalisation of power has become a relevant feature that instantiates the process of life fabrication. In this respect, as highlighted by Foucault (2003), power and knowledge are inseparable, which in turn, renders biotechnology as a tool designed to manipulate the pluripotency of life. Dillon and Lobo-Guerrero's (2008) assertion that life can now be instigated to come into being in different instances is perhaps the best description of the pluripotency of life. This process was rendered feasible by the molecularisation of biology which paved the way to the control and command the morphogenetic process itself. Rose (2007) sums up this new era as a period in which biotechnology controls the very production of living material irrespective of the specific forms in which it comes. Cooper (2015) also highlights that biotechnology refers to any intervention that seeks to disrupt, suspend, accumulate, and reanimate the temporal possibilities of the living body. In this sense, biopolitics allow for the 'pluripotency' of life to be controlled through the manipulation of time (see PFRIMER; BARBOSA JR, 2017).

The possibilities brought about by biotechnological artifacts are not immune to economic appropriation as means of (re)producing biocapital. In this respect, Waldby (2002) draws attention to what was called 'biovalue', as a way to represent new forms in which bodies and tissues are diverted for the conservation and improvement of the health 
and vitality of the being. Reappraising the idea of biovalue, Novas and Rose (2000) extended the application in order to encompass all the ways in which vitality itself has become a potential source of value. Therefore, the bioeconomy creates a new space of thought and action characterised by a network of corporations working on the many possibilities of exploring life for the reproduction of biocapital, ranging from the stem cell sector to equipment, reagents, and tissues.

In short, a result of its fungible nature, power can now be converted into different dimensions as permitted by the advances of technology to the various domains of life. This articulation of power with the numerous possibilities of space-time manipulation thus creates a complex scenario portrayed in Table 01 .

Table 01: Power dimensions in the molecular age

space time

\begin{tabular}{lll}
\hline political power & geopolitics (AGNEW, 2003) & biopolitics (BRAUN, 2007) \\
economic power & $\begin{array}{l}\text { geoeconomics (BECKER, } \\
\text { 2007) }\end{array}$ & bioeconomics (ROSE, 2007)
\end{tabular}

Org.: Table organised by the authors.

Even though territory and land, in terms of both fertility and extension, are meaningful in the exertion of power through agricultural production, as we have discussed, other assets became similarly relevant as expressions of power. First, access to biodiversity as a source of vitality. This is even more significant given that since the emergence of biopower, genetic resources became a relevant way to manipulate time in order to suit life's instance of reproduction to the needs of capital (re)production. Second, knowledge expressed in terms of biotechnology became crucial to expand power to other domains, particularly in the realm of agriculture (VALLAS; KLEINMAN, 2008). This is due to the possibilities offered by the breakthroughs of the Green Revolution and thereafter the Biotechnology Revolution, also called the Second Green Revolution, which allowed for the genetic manipulation of plants. This in turn, set the stage for evaluating and manipulating the pluripotency of life for economic purposes.

In sum, the analysis of land (territory), agrobiodiversity (life), and biotechnology (knowledge) as strategic assets in the contemporary global agricultural market allows us to better explore the contentions between state actors. This in turn, offers an analytical framework to better understand the dynamics of competition in the international agrifood market. Departing from this perspective, countries in the best position hold all three of these resources, and therefore, operate with greater autonomy. Other countries, in an intermediate position, that hold one or two of these resources, need to establish relations with additional countries, or other non-state actors, to effectively explore the 
aforementioned resources. In the least favorable position are countries that hold none of them and are largely dependent.

Given that both of these established polarities are virtually inexistent the bulk of countries would be situated somewhere in the intermediate position. The relations between these countries are what we explore in this paper. It is important to understand that in capitalism the control over the means of production, is more strategic than the control over the so-called 'raw' materials and this is similarly the context within the neoliberal free trade regime. Thus, even the countries that hold both agricultural land and agrobiodiversity do not maintain as high of a standing, nor do they profit as much. Therefore, a country that controls biotechnology but does not detain either vitality, to explore, nor fertile land, to grow food, can still dominate large sectors of the international agricultural market.

When it comes to global agrifood trade, the three resources in this framework land (territory), agrobiodiversity (life), and biotechnology (knowledge) - are all meaningful, but within the logic of the market, they are not equally significant. Neither knowledge nor the resulting capital accumulated from its instrumental use are by themselves sufficient towards ensuring the food security of a country and its population. Thus outside a market logic, this equation would be inverted, as neither knowledge nor capital can be immediately converted into food. This conception allows us to truly grasp what is essential without the value attributed by capitalist practices. Processes such as land grabbing and biopiracy demonstrate that even the states that most benefit from the neoliberal free trade regime are not willing to subject their interests exclusively to the market (BARBOSA JR; PFRIMER, 2016; SOYER; BARBOSA JR, 2018).

Although natural elements require technology in order to be converted into a commodity modified for the demands of the international market, food can still be grown without the use of biotechnology - as has long been done. Interestingly, agroecology is demonstrating to be similarly effective within a more ramified value structure (ALTIERI; TOLEDO, 2011; ALTIERI, 2009; LEVIDOW; PIMBERT; VANLOQUEREN, 2014). Agroecology is also upheld by technology, but for purposes beyond the narrow value scope of the market. In the current context o neoliberal trade neither the production nor the trade of food is done with a purpose other than that of capital (re)production, regardless of the rhetoric.

\section{Turning life into an asset: bioeconomics, biotechnology, and the process of commodifying life}

Ever since humans first started domesticating plants select food types have been preferred in relation to others. For example, in the Americas maize was favoured because it is easy to store (ACEMOGLU; ROBINSON, 2012). This selective breeding did not, however, result in uniformity but in diversity as farmers from different localities chose and bettered crops more adapted to their circumstances, such as weather, soil, and others (MAZOYER; ROUDART, 2006). In this sense, there was an array of biodiversity not only 
in food crops but also within types of specific food crops. In this section we illustrate how the instrumental use of biotechnology, directed by capitalist needs, has perverted the potentiality of this technique. Further on, we demonstrate how the use of biotechnology in the contemporary global agricultural market has been applied to foster the commodification of life in order to create what Rose (2007) conceptualised as bioeconomy. This process is largely characterised by the genetic standardisation of seeds through biopiracy and patents.

The term agrobiodiversity refers to the biodiversity of crop types and, hence, food items. This diversity is not only representative of the difference in plants that are fit for human consumption, but also the variety brought about by human action. For the selection of food types one chooses to breed is in itself a type of 'technology'. Human efforts have resulted in culturally acclimate food sources better suited to their environment and needs, and is representative traditional knowledge (AKSOY, 2014). The loss of agrobiodiversity is therefore the loss of ancient knowledge.

Nowadays the global food system as a whole, as well as the many specific food systems around the world that together compose it, are largely privatised. Still, much of the actual farming is still done by peasant and family farmers who occupy over $98 \%$ of farms globally (GRAEUB et al., 2015). Even when farming is not directly under the control of a large corporation, these often control the most basic resource of food production: the genetic material. Genetic resources are the basis of agriculture, placing it amongst the most vital of all our resources. FAO (1999) estimated that from 1990 to 2000 $75 \%$ of plant genetic diversity had been lost, as farmers worldwide left their multiple local varieties for genetically uniform cash crops. By directing the international market and determining global food consumption trends, corporations have simplified consumer diets paving the way for monocrop production.

It is undeniable that biotechnology could produce greater biodiversity through processes that generate different species of plants and the genetic modification of seeds. Nevertheless, in the molecular age, market rational has instrumentalised biotechnology, its resulting practices and techniques with the aim of turning all instances of life into an asset. This is best observed through the artificial creation of scarcity. Corporations genetically manipulate plants to produce sterile seeds, which in turn, force farmers to buy more seeds instead of (re)growing the seeds they harvest (CASTREE, 2001; KLOPPENBURG, 2004). In addition to the dependency this creates it also means that seeds are not continuously adapting, but instead always reset to its original form. Other mechanisms that produce artificial scarcity are depicted by Schumpeter (1976) as creative destruction, which impinges a certain form of production at the behest of others, such as the ones used in the appropriation of traditional knowledge. Resorting to patents in order to standardise production is a well-known procedure used to condense variety with the aim of regulating the market according to economic tenets.

As can be seen diversity was not incorporated in the process of globalised agricultural production, and as a result genetic erosion became one of its principal by- 
products. With agrobiodiversity only holding the value of vitality, as a possibility for future market exploration, the variety of plant life is held merely in terms of prospective future appropriation. Agrobiodiversity preservation occurring primarily for such reason. This process is documented by international organisations. According the Food and Agriculture Organisation of the United Nations (FAO, 2004:5):

The extension of industrial patenting, and other intellectual property systems, to living organisms has led to the widespread cultivation and rearing of fewer varieties and breeds. This results in a more uniform, less diverse, but more competitive global market. As a consequence there have been: - changes in farmers' and consumers' perceptions, preferences and living conditions; - marginalisation of small-scale, diverse food production systems that conserve farmers' varieties of crops and breeds of domestic animals; [...].

Traditional knowledge is largely disregarded by scientific practices. In other words, for not following academic tenets of truth validation, traditional knowledge is believed not worthy of confidence. Wherefore, most developed countries have since the Cold War started to implement new agricultural production technologies in developing countries. These policies have impinged exogenous understandings and techniques as a mechanism to standardise diversity in ways of producing and knowing about food. Further on, this has also represented a strategic mechanism to impose the practice and knowledge of developed countries as the standard to be reached and followed. This is one of the most significant factors in the drastic decrease of the biodiversity among agrifoods being traded. As remarked by Perkins (1997:25):

After 1945, however, governments began consciously to promote new technologies to develop other countries, which was a euphemism for promoting creative destruction. Perhaps development was one of the most ironic concepts to enter latetwentieth-century language, and in basic ways its meaning was tied to the results of plant-breeding science and the yield transformation.

Strikingly, what was once considered as of low-value for academic scrutiny, was soon rendered as a theme of high consideration. As traditional knowledge is translated into scientific language through mechanisms of scientific validation, they became something usable in accordance to the western scientific paradigm. Following this scientific tenet, value is only given to nature after it has been framed through western scientific principles and processed though western scientific procedures. Traditional knowledge can be easily appropriated within the precepts of the international legislation on intellectual property (KERCKHOFFS, 2012; KHO, 2012; WHITT, 2009). What follows, from these considerations, is that the knowledge of traditional communities is underqualified by the international agricultural market and hence, the use of biotechnology is imposed as the basis for producing valid knowledge. 
While analysing biopiracy and biocolonialism, Shiva (2001) calls attention to the historical process of appropriating nature. According to the author, the idea of terra nullius instantiates the very notion that in a certain sense what is public does not belong to anyone, and this therefore permits the expansion over indigenous peoples' territories and the exploitation of natural shared resources and knowledge (FRISON; COOLSAET, 2019). That is to say, that what is in or of nature and has no private owner is susceptible to be 'grabbed'. Following this rationale, Shiva asserts that something similar can be observed nowadays through the control over life. The molecular gaze proportioned by biotechnology has made life fabrication possible, and as such, has also allowed for greater biopiracy. Since life forms in this new stage can be easily appropriated, controlled, manipulated, and, finally, patented. To describe this novel situation, Shiva coined the term bio nullius. In an upshot, it means that what is in nature does not have any formal owner and because it has not been standardised, it is prone to becoming patented, due to the lack of scientific appraisal.

As shown, the creation of property rights on the basis of so-called 'scientific discovery' is an recurrent mechanism for despoiling traditional knowledge from peasant and indigenous communities (AKSOY, 2014). If at first, the legal principle of terra nullius was applied to legitimise the expansion over traditional communities' land. The very idea of bio nullius currently authorises the appropriation of life forms and their active principles in foreign lands. This occurs on the very brink of the capitalist process, since controlling the seed market is strategic for capitalist agriculture. Although, it is not per se the most profitable sector, the seed market is the most strategic, and is the cornerstone used control other more profitable sectors of the proactive chain (ETC GROUP, 2015).3 The creation of property rights via patenting has fashioned a judicial tool that allows for the land, life, and knowledge of peasant, indigenous and other traditional communities to be despoiled.

Such processes are responsible for the creation of a bioeconomy which represents the expansion of economic rationale to the scientific domain of life fabrication. As a result, this implies in an instrumentalisation of biotechnology that is turned into a tool for exerting power by controlling the various process of manipulating life for capital gain. The production of a bioeconomy relies on the manipulation of life to distort time in posit of temporalities more appropriate for global trade (PFRIMER; BARBOSA JR, 2017). This course engenders the construction of multiple spatialities of power, which will be analysed in the following section.

\footnotetext{
${ }^{3}$ For a map of the Seed Industry Structure from 1996 to 2018 organised by Dr. Phil Howard see <https://philhowardnet.files.wordpress.com/2018/12/Seed2018-1.pdf>
} 


\section{Demystifying deceitful food security rhetoric: geoeconomics and the spatiality of global agriculture trade}

In the international politics power does not restrict itself to the military (BARBOSA JR; LEAL, 2016). As Becker (2007) demonstrates the nature of conflict changes after the Cold War and new dimensions of power were unveiled. Luttwak (1997) asserts that geoeconomics is best depicted as the logic of conflict with methods of commerce, which implies a spatial architecture of infrastructures, bodies, flows, and networks required to succeed in commercial competition. Logistics, chains of production, place, and localisation are also important concerns when it comes to the global trade of agrifood products, which necessarily implies in a strategy of spatial organisation with the aim of reaching desired outcomes.

Global agrifood trade has expanded rapidly, with greater engagement becoming an inevitable part of most countries' national trade strategies (FAO, 2015). It is common for pro-market liberals to claim that the food traded internationally offers sufficient nutritional diversity and thus food security (see DE PAULA; PESSALI, 2015; NALLY, 2016). This, nonetheless, disregards the diversity of nutritional sources. In view of that, the diversity within international trade is rapidly depleting. There is need to analyse this process spatially (BERDEGUÉ; BEBBINGTON; ESCOBAL, 2015), similar to the approach used to map staple food cropping across Brazil (BROWN; RAUSCH; LUZ, 2014).

As previously discussed, the global process of food trade promotes interdependence between countries, irrespective to how unequal this dependency may be. There are positive market implications attributed to a country that moves towards specialised production, which further accentuates dependency. A double movement occurs, where not only is the industrial monocrop production model being widely implemented across the world, specific countries are likewise intently striving towards greater uniformity in an already restricted assortment of production that occurs within their national borders. Such a 'cloth and wine' arrangement causes greater interdependency and inequality amongst countries and within their population.

There is a recurrent argument that Brazil is making the best use of its resources by doing precisely what it best suited to do, that is, producing food for the world (see MARTINELLI; FILOSO, 2009; PAULA; BASTOS, 2009). Such rhetoric is made in accordance with the Smithsonian maximum, without understanding the structure and consequences that such project has. While Brazilian resources are being exported, under the promise of strengthening food security by modernising agriculture through rural development, peasant farmers are still responsible for most of the food on the table of Brazilian households. According to the last agricultural census while peasant have just $24 \%$ of the landholdings and $14 \%$ of public credit they produce $70 \%$ of the food consumed in Brazilian households and represent $74 \%$ of the jobs in the countryside (IBGE, 2006). Nonetheless, food is being grown within the capitalist agricultural paradigm in Brazil. 
Thus, there is need to ask: where is this food going; who or what is consuming it; what parties are benefiting from this; and at what cost?

The fact Brazil's agribusiness output is mostly exported to supply the commodity market is well known. What is less discussed is how this economically unsustainable model is heavily subsidised with Brazilian taxpayer money (BARBOSA JR; COCA, 2015b). Along the inaccurate belief that agribusiness production is feeding the national population, is the analog assumption that agrifood exports are feeding the world. As Figure 01 shows most of the grain produced globally is destined towards animal feed. Nonhumans are the primary consumers with humans only being indirect consumers. Few benefit from this a process, but they benefit greatly. Despite the compensation of global agricultural trade being restricted, the process is carried out at the expanse of all. The environment and the rural poor are most affected, but broader demographics such as urban food consumers are likewise impacted (COCA; BARBOSA JR, 2018).

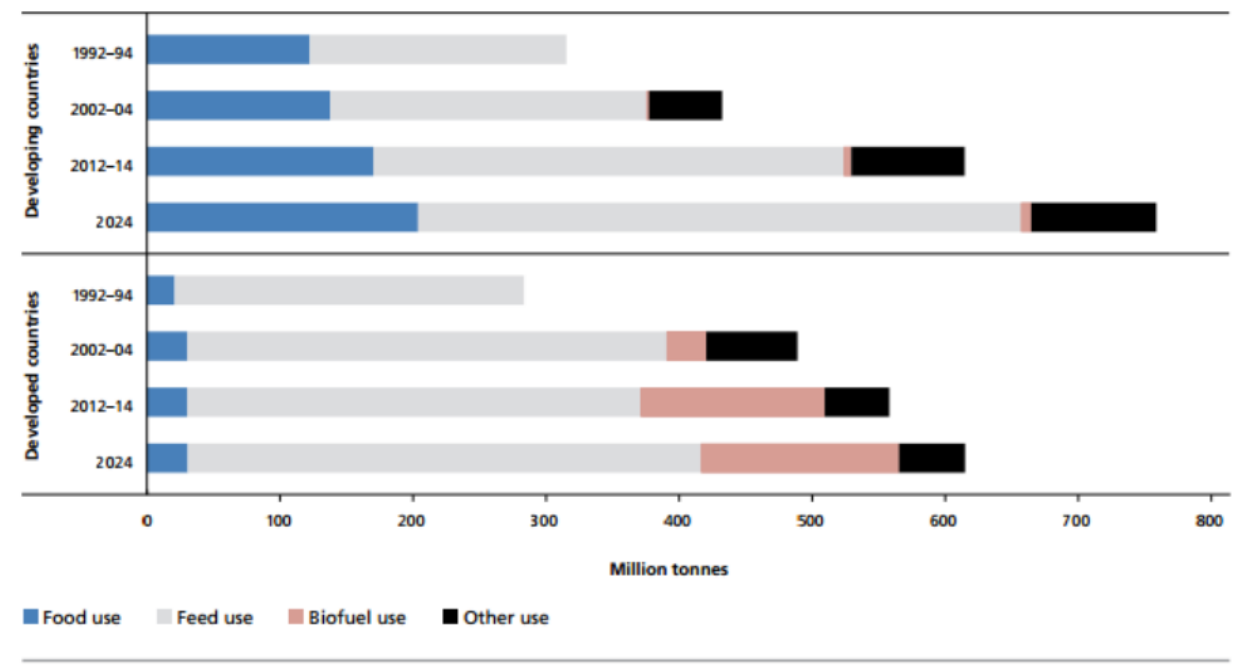

Figure 01: Coarse grain utilisation in developed and developing countries Source: FAO and OECD (2015)

Much of the commodity grain production is destined for non-humans and does not have food security implications as its direct object. Rather the culture and commerce of commodity grain can be better understood as a means of producing monetary value. In terms of the food system, it can only be marginally understood as means of 'feeding the hungry'. The North-South divide depicts this clearly as the amount of course grain used as a food source in so-called developed countries are notably lower than in those considered to be developing. Another important consideration is that developed countries are already devoting significant portions of their production towards biofuel (GAUDER; GRAEFF-HÖNNINGERR; CLAUPEIN, 2011). As per the projection, not only is this 
course set to increase, it is also set to start occurring in developing countries. Therefore, as Castro (1962) has revealed hunger is socially produced and not the result of natural processes. Pervasive economic relations among global actors offer advantages to some at the expense of others. A report with research from 44 countries depicts the impacts of the world's largest commodity traders on the modern food systems and demonstrates just how the global food system leaves nearly one billion people hungry (MURPHY; BURCH; CLAPP, 2012).

\section{Soybean export flows}

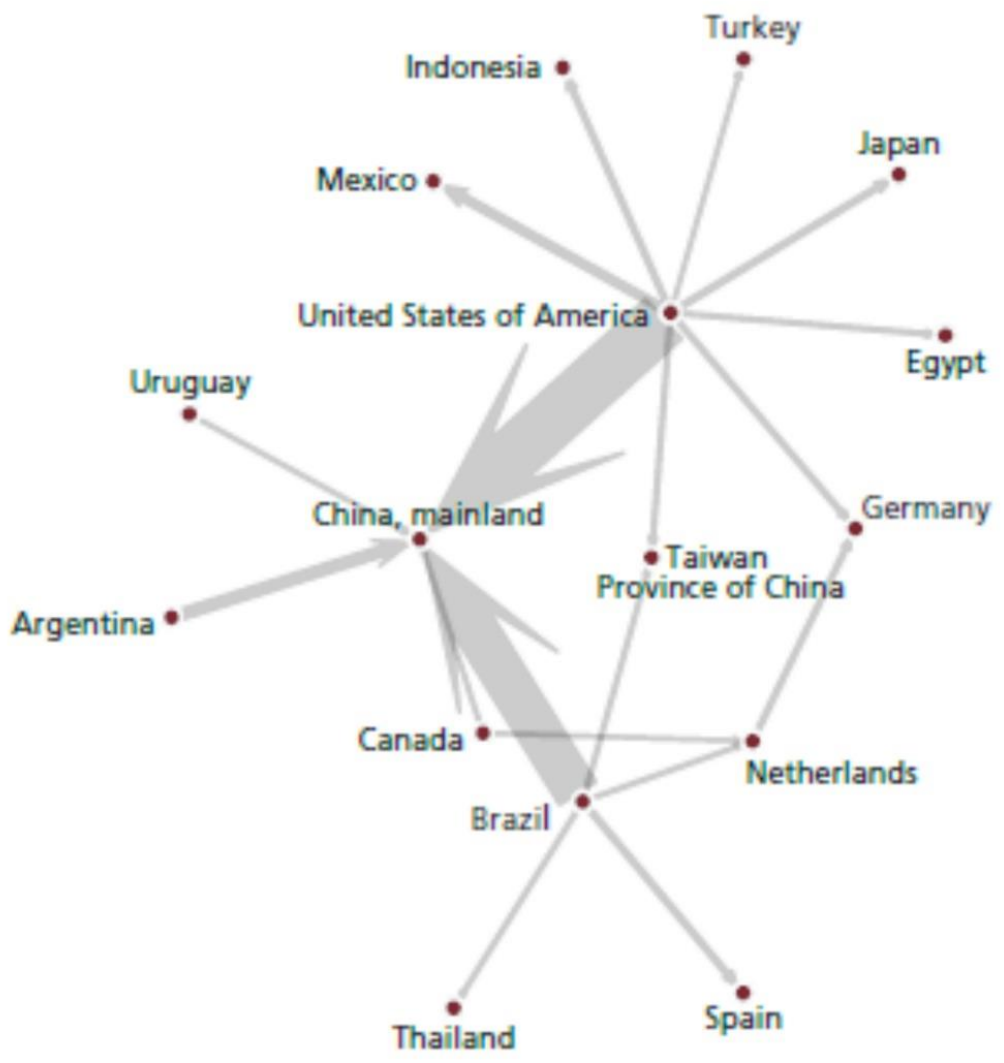

Figure 02: Soybean export flows (2012)

Source: FAO (2015) 
Global economic dynamics are changing, and the emergence of different economies denotes new implications for consumers. Specifically worrisome are new consumer preferences, arguably imposed by the system itself (OOSTERVEER, 2007), of the two most populous countries in the world, China and India. Both of these BRICS countries have a steadily rising middle class that are demanding more meat. A food type now perceived as a consumer item. Higher consumption of meat is novel to consumer diets that were before only sparsely based on the product (WEIS, 2013), and has had significant implications for international agrifood market. For instance, by the end of the 2000s China had become Brazil's largest trading partner, with most of its agricultural output being directed towards that country. China is the principal recipient of Brazil's main agriculture export, soy - see Figure 02.

Figure 02 portrays the flow of soybean export and import among countries. The United States, Brazil, and Argentina, the main global producers and exporters of soybeans respectively, all trade significant portions of their production with a single recipient: China. The country occupies a central position as the main importer. The spatial distance among the three main exporting states and the final consumer market is noteworthy. A robust trade system is implemented by the global commodity market with enormous strategic infrastructure and multiplicity of networks are needed to allow soybeans to reach its final destination. The logistic and economic chains are composed of a complex grid of spatial arrangements and infrastructures deployed at the right place and precise time (COWEN, 2014), which characterizes geoeconomic competition among various states and multiple corporations that strive to organise space according to their priorities (LUTTWAK, 1997). For this purpose, geoeconomics coalesce with bioeconomics since genetic modification of seed vitality is essential to make them uniform and long-lasting, and ultimately able to be processed by diverse machinery and maintain its characteristics during the whole distance between where they are produced and the final destination.

Oil seeds are Brazil's number one export, representing a 21.2 billion dollar market and composes $11.1 \%$ of total national exports (WTEx, 2016). Interestingly, soy which was adapted by the national public agricultural research corporation EMBRAPA to grow in the Brazilian Cerrado region (CLEMENTS; FERNANDES, 2013; NEHRING, 2016; PFRIMER; BARBOSA JR, 2016) - is not originally from the Americas, but from China the very country where most of the export is destined. We are planting crops from elsewhere, with an agricultural model that is not our own at the cost of our native environment, radically altering what remains, in efforts to supply other countries, and we are not even doing this to feed their population but to supply an unsustainable marketinduced meat eating trend.

As Michael Pollan (2008:124) puts it,

It's no accident that the small handful of plants we've come to rely on are grains (soy is a legume); these crops are exceptionally efficient at transforming sunlight, fertiliser, air, and water into macronutrients - carbohydrates, fats, and proteins. These 
macronutrients in turn can be profitably converted into meat, dairy, and processed foods of every description. Also, the fact that they come in the form of durable seeds which can be stored for long periods of time means they can function as commodities as well as foods, making these crops particularly well adapted to the needs of industrial capitalism. The needs of the human eater are a very different matter, however.

Thus, we can conclude that the international agricultural market leaves little space for agrobiodiversity because it is directed towards profit, not the preferences and needs of human consumers. Homogeneous commodities that can be stored for long periods and thus able to travel long distances are better suited for global trade. Nutritionally this is also a problem, as 'we are also what we eat, eats'.

\section{Discussion}

Neoliberalism is characterised by the retreat of the state in favour of business interests and practices (STRANGE, 1998). And in fact, the state has been largely reduced to offering incentives and opportunities by means of corporate-friendly policies (STOPFORD; STRANGE; HENLY, 1998). Yet, global agricultural trade requires broad far-reaching logistic infrastructure as local production is not the priority. As such, the framework proposed in this paper allows us to recognise that global agricultural trade is the result of a withdrawal of state and greater autonomy conceded to industrial capitalist initiatives, but likewise relies expressly on the selective action of the state to adapt crop types, built infrastructure, attract foreign investors, broker deals, offer credit, suppress dissidence, and much more. Authors that adhere to food regime theory (FRIEDMANN; MCMICHAEL, 1989) recognise that neoliberalism is characterized by the role large corporations exert in geopolitics, but do not deny the relevance of the state. It is important to recognise that the state is not totally absent, as markets depend on the state system and its institutional foundations, rather, there is a tactical retreat to allow for the advance of capital (ROCHA; BARBOSA JR, 2018). The state continues to play a strong role in creating conditions for regulation and action.

Although adapting crops to deferent regions around the globe is not necessarily undesirable, we need to recognise that there is a cost to doing so. As we show in the paper, rather than contributing to the nutrition of local populations, this process has direct market implications. Altering food crops is a deliberately strategic process that uses genetic resources as a means to establish markets as well as to implementing and maintaining trade. This benefits few, at the cost agrobiodiversity, and has clear market value adding directives. In many ways, the loss of genetic diversity is also loss of sovereignty for both the farmer and the country. Peasants lose their seed autonomy and the natural resilience that the genetic diversity provides, being forced into the market and its industrial highinput agriculture. States are similarly effected as national agricultural policies become 
directed by pressure groups that lobby in favor of exogenous interests, and have their natural resources appropriated and eroded.

Facing the harsh consequences of such an indiscriminate global free trade system, the rural poor from the global south have begun to articulate through a coalition of social movements called La Vía Campesina, which is resisting this process whiles also demonstrating that an alternative way of (re)envisioning and doing agriculture is possible (ALTIERI; TOLEDO, 2011). The concept of food sovereignty emerged through this struggle (CHAPPELL et al., 2013; WITTMAN; DESMARAIS; WIEBE, 2010), and in turn the notion of seed sovereignty (KLOPPENBURG, 2010). The grassroots proposal of food sovereignty establishes the new paradigm of local consumption, which aims to reduce pathways, shortening the distance between producer and consumer (COCA; BARBOSA JR, 2016). Whereas the logistics of the global food system is based on long distances, food sovereignty advocates for local food networks, based on shorter distances that would be much more inclusive of diversity.

Although FAO (2015, unpaginated) understands food sovereignty as "centred on reducing global food trade and reorienting food systems around local production grounded in agroecological principles." Authors such as Burnett and Murphy (2014) argue that international commerce is not advert to food sovereignty, and that trade remains important to the realisation of the livelihoods of small-scale producers and the promotion of food security. We need to consider this, but with caution, for the same way organic food was incorporated as niche market sector for consumers with high purchasing power, a similar process can occur with agrifood products internationally (FREIDBERG, 2003). It is essential that this be done in a way that allows for food to be grow and consumed democratically. So as not to be just another 'fell good solution' sold within the market.

In short, if food varieties are being reduced and the sum of food consumed is constantly increasing, it stands to reason that choices are being made as to what crops will and consequently will not be planted. Yet, quality, nutrition, and flavor are not the determining factors computed in these decisions, but rather economic directives that are a result of market-oriented dynamics. Such as capacity to store and transport, amount of output yield, percentage of protein and capacity to become feed or industrialised foods.

\section{Final considerations}

Ideas shape development. Thus the need for research that is critical of the ways development is being projected and pursued. Trade is important for development; however, academics have the task of drawing attention to consequences that underpin processes such as these. While international commerce can affect a countries level of development, global food trade is not structured to incorporate biological variety. Two processes are required to address this. The general population needs to become conscious it is taking place and future food programs and policies need to become more inclusive of food diversity. 
As we explored the factors that determine the place of genetic resources in international trade, it has become apparent that biotechnology plays a significant role. This is particularly problematic in terms of technological dependency (MOREIRA JR, 2014), but even so biotechnology is not the problem. The concern is that biotechnology is almost exclusively used within agriculture as a tool of the market. Interesting proposals, such as the notion of open source biology (KLOPPENBURG, 2010, 2014), are being suggested and would be a step in the direction of resolving the issue. Rather than technology itself, it's instrumentalisation as a means of exerting power and accumulating wealth is what is pervasive. Especially for countries that have natural resources and no technology.

\section{References}

ACEMOGLU, D.; ROBINSON, J. A. Why Nations Fail: The Origins of Power, Prosperity, and Poverty. 1. ed. New York: Crown Publishers, 2012.

AGNEW, J. Geopolitics: re-visioning world politics. 2. ed. New York: Routledge, 2003.

AKSOY, Z. Local-Global Linkages in Environmental Governance: The Case of Crop Genetic Resources. Global Environmental Politics, v. 14, n. 2, p. 26-44, 2014.

ALKON, H. A. Food Justice, Food Sovereignty and the Challenge of Neoliberalism. Food Sovereignty: A Critical Dialogue, p. 1-25, 2013.

ALONSO-FRADEJAS, A. et al. Food sovereignty: convergence and contradictions, conditions and challenges. Third World Quarterly, v. 36, n. 3, p. 431-448, 2015.

ALTIERI, M. A.; TOLEDO, V. M. The agroecological revolution in Latin America: rescuing nature, ensuring food sovereignty and empowering peasants. The Journal of Peasant Studies, v. 38, n. 3, p. 587-612, 2011.

ALTIERI, M. A. Agroecology, small farms, and food sovereignty. Monthly Review, p. 102-114, 2009.

BARBOSA JR, R.; COCA, E. L. DE F. The WTO's international multilateral trade system and its effects on the production and consumption of food. Boletim Meridiano 47, v. 16, n. 150, p. 42-49, 2015 a.

BARBOSA JR, R.; COCA, E. L. DE F. Conflitos entre o campesinato e o agronegócio no Brasil: os planos-safra 2015-2016. Eutopía, v. 8, p. 13-27, 2015 b.

BARBOSA JR, R.; LEAL, J. B. S. Uma abordagem foucaultiana das relações internacionais: os processos de integração regional a partir da concepção de dinâmica de poder. Revista de Defesa e Segurança, v. 1, p. 201-224, 2016.

BARBOSA JR, R.; PFRIMER, M. H. Shortcomings of global multilateral agrifood trade and a new food-dependency-based protagonism. Conjuntura Internacional, v. 13, n. 1, p. 96-103, 2016. 
BECKER, B. K. Reflexões sobre a Geopolítica e a Logística da Soja na Amazônia. In: BECKER, B. K.; ALVES, D.; COSTA, W. DA (Eds.). Dimensões Humanas da Biosfera-Atmosfera na Amazônia. 1. ed. São Paulo: Editora da Universidade de São Paulo, 2007. p. 113-128.

BERDEGUÉ, J. A.; BEBBINGTON, A.; ESCOBAL, J. Conceptualizing Spatial Diversity in Latin American Rural Development: Structures, Institutions, and Coalitions. World Development, v. 73, p. 1-10, 2015.

BRAUN, B. Biopolitics and the molecularization of life. Cultural Geographies, v. 14, n. 1, p. 6-28, 2007.

BROWN, J. C.; RAUSCH, L.; LUZ, V. G. Toward a Spatial Understanding of Staple Food and Nonstaple Food Production in Brazil. The Professional Geographer, v. 66, n. 2, p. 249-259, 2014.

BURNETT, K.; MURPHY, S. What place for international trade in food sovereignty? Journal of Peasant Studies, v. 41, n. 6, p. 1065-1084, 2014.

CASTREE, N. Marxism, Capitalism, and the Production of Nature. In: CASTREE, N.; BRAUN, B. (Eds.). Social Nature. 1. ed. Malden: Blackwell Publishing, 2001. p. 189207.

CASTRO, J. DE. Geopolítica del Hambre: ensayo sobre los problemas alimentarios y demográficos del mundo. 3. ed. Buenos Aires: Solar/Hachette, 1962.

CHAPPELL, M. J. et al. Food sovereignty: an alternative paradigm for poverty reduction and biodiversity conservation in Latin America. F1000Research, v. 2, n. November 2015, p. 235, 2013.

CLAPP, J.; FUCHS, D. Corporate Power in Global Agrifood Governance. Cambridge/Massachusetts/Londres: MIT Press, 2009.

CLEMENTS, E. A.; FERNANDES, B. M. Land Grabbing, Agribusiness and the Peasantry in Brazil and Mozambique. Agrarian South: Journal of Political Economy, v. 2, n. 1, p. 41-69, 2013.

COCA, E. L. DE F.; BARBOSA JR, R. (Re)Approximating food producers and consumers in Metro Vancouver, Canada. Dimensión Empresarial, v. 14, n. 1, p. 11-26, 2016.

COCA, E. L. DE F.; BARBOSA JR, R. Responding to neoliberal diets: school meal programmes in Brazil and Canada. In: GRAY, A.; HINCH, R. (Eds.). A handbook of food crime: immoral and illegal practices in the food industry and what to do about them. Bristol: Policy Press, 2018. p. 347-363.

COOPER, M. In vivo economies: temporalities of life and value. Journal of Cultural Economy, v. 8, n. 3, p. 257-259, 2015. 
COWEN, D. The Deadly Life of Logistics: Mapping Violence in Global Trade. Minneapolis: Minnesota University Press, 2014.

DE PAULA, N.; PESSALI, H. Agricultural Trade Negotiations and the Challenges of Food Security. Agrarian South: Journal of Political Economy, v. 3, n. 3, p. 313-335, 2015.

DELANEY, D. Territory: a short introduction. Malden: Blackwell Publishing, 2005.

DILLON, M. G.; LOBO-GUERRERO, L. Biopolitics of security in the 21st century: An Introduction. Review of International Studies, v. 34, p. 265-292, 2008.

ETC GROUP. Mega-Mergers in the Global Agricultural Inputs Sector: Threats to Food Security \& Climate Resilience. Ottawa: [s.n.]. 2015.

FAO. Women - users, preservers and managers of agrobiodiversity. Rome: [s.n.]. 1999.

FAO. Building on Gender, Agrobiodiversity and Local Knowledge: What is Agrobiodiversity? Rome: [s.n.]. 2004.

FAO. The State of Agricultural Commodity Markets 2015-16 (SOCO) "Trade and food security: achieving a better balance between national priorities and the collective good". Rome: [s.n.]. 2015.

FAO; OCDE. Agricultural outlook 2015-2024. Paris: [s.n.]. 2015.

FOUCAULT, M. "Society Must Be Defended": Lectures a the Collège de France, 197576. New York: Picador, 2003.

FREIDBERG, S. E. Culture, conventions and colonial constructs of rurality in southnorth horticultural trades. Journal of Rural Studies, v. 19, n. 1, p. 97-109, 2003.

FRIEDMANN, H. Changes in the international division of labor: Agri-food complexes and export agriculture. In: FRIEDLAND, W. (Ed.). Towards a New Political Economy of Agriculture. Boulder: Westview Press, 1991. p. 65-93.

FRIEDMANN, H.; MCMICHAEL, P. Agriculture and the state system: The rise and decline of national agricultures, 1870 to the present. Sociologia Ruralis, v. 29, n. 2, p. 93-117, 1989.

FRISON, C.; COOLSAET, B. Genetic resources for food and agriculture as commons. In: VIVERO-POL, J. L. et al. (Eds.). Routledge hanbook of food as commons. New York: Routledge, 2019. p. 218-230.

GAUDER, M.; GRAEFF-HÖNNINGERR, S.; CLAUPEIN, W. The impact of a growing bioethanol industry on food production in Brazil. Applied Energy, v. 88, n. 3, p. 672-679, 2011.

GOTTMANN, J. The Significance of Territory. 1. ed. Charlottesville: [s.n.]. 1973. 
GRADDY, T. G. Regarding biocultural heritage: In situ political ecology of agricultural biodiversity in the Peruvian Andes. Agriculture and Human Values, v. 30, n. 4, p. 587604, 2013.

GRADDY, T. G. Situating in situ: A critical geography of agricultural biodiversity conservation in the peruvian andes and beyond. Antipode, v. 46, n. 2, p. 426-454, 2014.

GRAEUB, B. E. et al. The State of Family Farms in the World. World Development, v. 87, p. 1-15, 2015.

HARVEY, D. The condition of postmodernity: an enquiry into the origins of cultural change. Cambridge: Blackwell Publishing, 1992.

IBGE. Censo Agropecuário de 2006. Rio de Janeiro: [s.n.]. 2006.

INGRAM, A. The Geopolitics of Disease. Geography Compass, v. 3, n. 6, p. 2084 2097, 2009.

KERCKHOFFS, D. Resisting the Colonization of "Life": Technoscience, Feminist Critique and Contemporary Art. [s.1.] Universiteit Utrecht, 2012.

KHO, T.-Y. Intellectual Property Rights and the North-South Contest for Agricultural Germplasm: A Historical Perspective. [s.l: s.n.]. v. 1

KLOPPENBURG, J. Impeding dispossession, enabling repossession: Biological open source and the recovery of seed sovereignty. Journal of Agrarian Change, v. 10, n. 3, p. 367-388, 2010.

KLOPPENBURG, J. Re-purposing the master's tools: The Open Source Seed Initiative and the struggle for seed sovereignty. Journal of Peasant Studies, v. 41, n. 6, p. 12251246, 2014.

KLOPPENBURG, J. R. First the seed: The political economy of plant biotechnology, 1492-2000: Second edition. 2. ed. Madison: The University ofWisconsin Press, 2004.

LEVIDOW, L.; PIMBERT, M.; VANLOQUEREN, G. Agroecological Research : Conforming — or Transforming the Dominant Agro-Food Regime? Agroecology and Sustainable Food Systems, v. 38, n. 10, p. 1127-1155, 2014.

LUTTWAK, E. N. From Geopolitics to Geo-Economics: Logic of Conflict, Grammar of Commerce. In: TUATHAIL, G. Ó.; DALBY, S.; ROUTLEDGE, P. (Eds.). The Geopolitics reader. London and New York: Routledge, 1997. p. 125-130.

MARTINELLI, L. A.; FILOSO, S. Balance between food production, biodiversity and ecosystem services in Brazil: a challenge and an opportunity. Biota Neotropica, v. 9, n. 4, p. 21-25, 2009.

MAZOYER, M.; ROUDART, L. A History of World Agriculture: From the Neolithic Age to the Current Crisis. New York: Monthly Press Review, 2006. 
MCMICHAEL, P. Peasant Prospects in the Neoliberal Age. New Political Economy, v. 11, n. 3, p. 407-418, 2006.

MCMICHAEL, P. Historicizing food sovereignty. Journal of Peasant Studies, v. 41, n. 6, p. 933-957, 2014.

MOREIRA JR, H. Reflexões Sobre Desenvolvimento, Inovação e Competição Internacional. Textos de Economia, v. 17, n. 2, p. 9-30, 2014.

MURPHY, S.; BURCH, D.; CLAPP, J. Cereal Secrets: The World's Largest Commodity Traders and Global Trends in AgricultureOxfam Research. London: [s.n.]. 2012.

NALLY, D. Against Food Security: On Forms of Care and Fields of Violence. Global Society, v. 30, n. 4, p. 558-582, 2016.

NEHRING, R. Yields of Dreams: State Building and the Politics of Scientific Knowledge in the Brazilian Agricultural Research Corporation (Embrapa). Geoforum, v. 77, p. 206-217, 2016.

NOVAS, C.; ROSE, N. Genetic risk and the birth of the somatic individual. Economy and Society, v. 29, n. 4, p. 485-513, 2000.

OOSTERVEER, P. Global governance of food production and consumption: issues and challenges. p. 294 pp., 2007.

OTERO, G. The neoliberal food regime in Latin America: state, agribusiness transnational corporations and biotechnology. Canadian Journal of Development Studies / Revue canadienne d'études du développement, v. 33, n. 3, p. 282-294, 2012.

PATEL, R. The Long Green Revolution. Journal of Peasant Studies, v. 40, n. 1, p. 1-63, 2013.

PATNAIK, P. The Peasant Question and Contemporary Capitalism: Some Reflections with Reference to India. Agrarian South: Journal of Political Economy, v. 1, n. 1, p. 27 42, 2012.

PAULA, N. DE; BASTOS, L. T. Brazilian agribusiness's insertion in global markets. Estudos Sociedade e Agricultura, v. 17, n. 2, p. 304-331, 2009.

PERKINS, J. H. Geopolitics and the Green Revolution: Wheat, Genes, and the Cold War. 1. ed. New York: Oxford University Press, 1997.

PFRIMER, M. H.; BARBOSA JR, R. Neo-agro-colonialism, control over life, and imposed spatio-temporalities. Contexto Internacional, v. 39, n. 1, p. 9-33, 2017.

PFRIMER, M. H.; BARBOSA JR, R. C. (De)Securitizing collectives of the Brazilian Cerrado and the implementation of an agribusiness complex. Revista NERA, v. 19, n. 30, p. 66-87, 2016. 
PFRIMER, M. H.; COCA, E. L. DE F.; BARBOSA JR, R. Biopolitics, Social Movements and Genetic Resources: The Case of PAA Seeds. Boletim Goiano de Geografia, v. 36, n. 2, p. 221-239, 2016.

POLLAN, M. In Defence of Food: an Eater's Manifesto. The Pengui ed. New York: [s.n.]. 2008.

RATZEL, F. La Géographie politique: Les concepts fondamentaux. Paris: Fayard, 1987. ROCHA, P. V.; BARBOSA JR, R. Criminalizar é governar: uma proposta teórica para a compreensão da criminalização dos movimentos sociais do campo no Brasil. Colombia Internacional, n. 93, p. 205-232, 2018.

ROSE, N. Molecular Politics, Somatic Ethics, and the Spirit of Biocapital. Social Theory \& Health, v. 5, n. 1, p. 3-29, 2007.

SCHUMPETER, J. A. Capitalism, Socialism and Democracy. 3. ed. New York: Harper and Row, 1976.

SHIVA, V. Protect or Plunder: Understanding Intellectual Property Rights. London: Zed Books Ltd., 2001.

SOYER, G. D. A.; BARBOSA JR, R. Estrangeirização de terras nas Relações Internacionais do Brasil. Contextualizaciones Latinoamericanas, v. 10, n. 18, p. 1-16, 2018.

STÉDILE, J. P. Capitalismo e política alimentar: o mundo não pode ser um grande supermercado. envolverde: Jornalismo \& Sustentabilidade, p. 1-3, out. 2013.

STOPFORD, J. M.; STRANGE, S.; HENLY, J. S. Rival States, Rival Firms: Competition for world market shares. Cambridge: Cambridge University Press, 1998.

STRANGE, S. The Retreat of the State: The Diffusion of Power in the World Economy. Cambridge: Cambridge University Press, 1998.

VALLAS, S. P.; KLEINMAN, D. L. Contradiction, convergence and the knowledge economy: The confluence of academic and commercial biotechnology. Socio-Economic Review, v. 6, n. 2, p. 283-311, 2008.

VAN DER PLOEG, J. D. Peasants and the art of farming: a chayanovian manifesto. Halifax/Winnipeg: Fernwood Publishing, 2016.

WALDBY, C. Stem Cells, Tissue Cultures and the Production of Biovalue. Health:, v. 6, n. 3, p. 305-323, 2002.

WEIS, T. The meat of the global food crisis. Journal Of Peasant Studies, v. 40, n. 1, p. 65-85, 2013.

WHITT, L. Science, Colonialism, and Indigenous Peoples: The Cultural Politics of Law and Knowledge. Cambridge: Cambridge University Press, 2009. 
WITTMAN, H.; DESMARAIS, A. A.; WIEBE, N. (EDS.). Food sovereignty: reconnecting food, nature and community. Halifax, Canada: Food First Books, 2010.

WTEX. Brazil's Top 10 Exports. Disponível em: <http://www.worldstopexports.com/brazils-top-10-exports/>. Acesso em: 15 fev. 2016. 2016.

ZIMMERER, K. S. Biological Diversity in Agriculture and Global Change. Annual Review of Environment and Resources, v. 35, n. 1, p. 137-166, 2010.

\section{Ricardo Barbosa Jr}

Geography MA student and Mitacs Globalink Fellow at the Department of Geography, University of Calgary - Canada. He holds a BA in International Relations from the Federal University of Goiás - Brazil.

Room 448, Earth Sciences Building, Department of Geography, University of Calgary 2500, University Dr. NW, Calgary AB, T2N 1N4, Canadá

E-mail: ricardo.barbosajr@ucalgary.ca.

\section{Matheus Hoffmann Pfrimer}

Professor of Geopolitics and Security Studies in the International Relations Program at the Faculty of Social Sciences, Federal University of Goiás (UFG), Brazil. He holds a $\mathrm{PhD}$ in Political Geography from the University of São Paulo (USP), having also conducted post-doctoral research at the same institution. Dr. Pfrimer holds a Master's degree in International Relations from Liège University, Belgium, and Bachelors' degrees in both Law (from the Pontifical Catholic University of Goiás - PUC-GO) and Geography (from the Federal University of Goiás - UFG), Brazil. He is currently a Researcher at the Center for Global Studies (NEG), where he holds a grant from the Goiás Research Foundation (FAPEG).

Faculdade de Ciências Sociais, Universidade Federal de Goiás - Campus II, Samambaia - 74690900 - Goiânia, GO - Brasil

E-mail: matheuspfrimer@hotmail.com

Recebido para publicação em fevereiro de 2018 Aprovado para publicação em maio de 2018 